\title{
Genetically Engineered Insulin Mediated by Glucose Transporter-2 (GLUT2) Promoter for the Biosynthesis of Insulin in Rat Hepatocytes: Insulin Gene Therapy
}

Gehad Abdallah ( $\sim$ gehadelsayedkg@gmail.com )

Genetic Department, Alexandria University

\section{Research}

Keywords: Gene therapy, GLUT2 promoter, Hepatocytes, Insulin, Mutation, Preproinsulin, Transfection, Vector.

Posted Date: January 19th, 2021

DOl: https://doi.org/10.21203/rs.3.rs-148725/v1

License: (9) This work is licensed under a Creative Commons Attribution 4.0 International License. Read Full License 


\section{Abstract}

Background: Expression of insulin in hepatocytes by hepatic gene therapy is a promising treatment of diabetes. The conversion of immature proinsulin to mature insulin occurs only in cells that contain the enzymes responsible for the cleavage of proinsulin to insulin.

Results: I engineered rat proinsulin with the sites of cleavage (Furin Cleavable Sites) using site directed mutagenesis for removal of $\mathrm{C}$-peptide to form the two chains $\mathrm{A}$ and $\mathrm{B}$ for mature insulin production. This engineered proinsulin was constructed into a non-viral expressing vector and regulated by glucose transporter-2 promoter to control the amount of mature insulin expressed, and to modulate the amount of glucose found in hepatocytes. The mature, active and regulated expressed insulin was secreted according to the amount of glucose regulated by the glucose transporter-2 promoter.

Concolusion: For successful hepatic insulin gene therapy, insulin production must be tightly coupled to glucose concentration. Hepatocytes are excellent target cells for insulin gene therapy since, they are similar to pancreatic beta cells, they have the ability to rapidly adapt to blood glucose concentrations as they possess glucose-sensing components, such as Glucose Transporter-2.

\section{Introduction}

Diabetes mellitus (DM) is a chronic disease that occurs when the body cannot produce enough insulin or cannot use insulin effectively (Harris \& Zimmet, 1985). It is characterized by chronic hyperglycemia together with disturbances of carbohydrate, fat and protein metabolism resulting from defects of insulin secretion, insulin action or both (WHO,1999). Insulin is a hormone produced in the pancreas that stimulates glucose uptake from the food from blood to enter the body's cells where it is converted into energy needed by muscles and tissues to function (Meslier et al., 2003). Insulin is a 5808-Da two-chain protein that is produced from a single-chain precursor, proinsulin, in the pancreatic beta cells of all mammals (Barcinskiand \& Rosenthal, 1977). The proteolytic enzymes immediately cleave the signal peptide, generating proinsulin (Ashcroft et al., 1987). proinsulin, comprising three peptides linked by two pairs of basic residues in the following order: Bchain-Arg-Arg-Cpeptide-Lys-Arg Achain (Schwartz , 1990). $C$ peptide is cleaved off from proinsulin at the adjacent dibasic residues during its transport through the trans-Golgi networks to immature-type secretory vesicles (Orci et al., 1987).

Gene therapy as a novel field of medicine holds tremendous therapeutic potential for a variety of human diseases including Insulin dependent Diabetes Mellitus (IDDM) (Selden et al., 1987; Hohmeier et al., 1997 ; Docherty, 1997 ; Tuch et al.,2003 and Nett et al., 2003 ). The beta ( $\beta$ ) cell has the ability to regulate insulin production at the transcriptional, post-transcriptional, translational, and post-translational levels, as well as the ability to store and secrete insulin in a highly regulated fashion. In response to glucose, $\beta$ cells have the ability to sense and quickly respond to small changes in circulating glucose levels over a broad range of physiological concentrations $(2-20 \mathrm{mM})$ through concentration dependent entry and 
metabolism of glucose (Won, Rhee \& Ko, 2009); they do so through the activity of glucose transporter-2 (GLUT2) and glucokinase.

For insulin gene therapy to be achieved, several criteria must be considered. First, the appropriate cells must be targeted for insulin production. At a minimum, these cells would need to express the glucose sensors, GLUT2 and glucokinase. Second, insulin transgene expression must be responsive to fluctuating blood glucose levels, being up regulated during hyperglycemia and down regulated during euglycemia. Third, there must be some mechanism in place for the target cell to process proinsulin into mature insulin. Lastly, an appropriate gene correction tool must be utilized to safely and effectively drive longterm insulin expression (Handrof, Sollinger \& Allam, 2016). The more active site in the GLUT2 promoter which is more active in the primary rat hepatocytes is from -500 to +240 (Mitchell \& Tjian, 1989 ; Neuberg et al., 1989 and Ahn et al., 1995). For engineering insulin-producing capacity, two types of cells are available: neuroendocrine and non- neuroendocrine. Upon extracellular stimulation, neuroendocrine cells exocytose secretory granules containing a mature bioactive peptide hormone that is converted from its precursor propeptide. This cell type may correspond to the mode of action of rapid-acting insulin (Lu et al., 1998). On the other hand, non-neuroendocrine cells, such as hepatocytes or muscle cells, are easily obtained, but unlike neuroendocrine cells, must be engineered with a processing mechanism and a regulatory secretion system( Kahn \& Weir, 1994).

Weaker tissue-specific promoter has been employed for hepatic insulin gene therapy to not only reduce the potential for hypoglycemia but also to improve targeting to the tissue of choice. The liver-specific GLUT2 promoter drive insulin gene expression in a glucose-inducible but insulin-repressive fashion and found an improvement in diabetic hyperglycemia (Burkhardt et al., 2005). Non-viral method was used to drive the expression of insulin into hepatocytes, because it is safer and including less of an immune response.

Adult rat hepatocytes in short-term primary culture are able to respond to hormones and nutrients as well as they do in vivo and often present a higher level of transcription of liver-specific genes than differentiated hepatoma cells (Jefferson et al., 1984).

\section{li. Procedure}

\section{A. Construction of the mutated rat preproinsulin cDNA}

The genomic rat DNA was extracted from the liver by TIANamp genomic DNA extraction kit (TIANgen kit), amplification the gene of interest by PCR using 2xTagPCR Mastermix using the designed preproinsulin primers;

Forward: CATGGCCCTGTGGATGCGCTTCCTGCCCCTG

Reverse: GAGTTGCAGTAGTTCTCCAGTTGGTAGAGGA 
The amplified gene was run on agarose gel electrophoresis to confirm the band size of the amplified preproinsulin gene (about 333bp), then sequenced and introduced to the linearized cloning vector (NEB PCR Cloning Kit\#E1202). After cloning the preproinsulin inside was ready for the mutation (Q5SiteDirectedMutagenesis Kit\# E0554S) to create the two furin cleavable sites inside the preproinsulin gene to get the mutated preproinsulin.

A variety of site directed mutations to engineer proinsulin to be a substrate for furin enzyme. This enzyme (also known as Paired basic Amino acid Cleaving Enzyme, PACE) is a Golgi-associated propeptide endoprotease that is present in the constitutive secretory pathway of virtually all cells. The introduction of furin consensus sequences at the B-chain/C-peptide and C-peptide/A-chain junctions to create tetra basic furin cleavage site. So, we engineered a cDNA for furin-cleavable rat proinsulin that will be efficiently processed to mature insulin. To perform this mutation in the preproinsulin which is cloned inside the cloning vector, we needed to make a mutation by substitution using a Q5 Site-Directed Mutagenesis Kit (\#E0554S) to change the three mentioned amino acids (glutamic acid to lysine, valine to arginine in the Cpeptide connecting to B-chain, and glutamine to arginine in the C-peptide connecting to A-chain ) (Figure 1 and Figure 2).

The primers for mutation were designed as follows according to the NEBaseChanger, which could be found at NEBaseChanger.neb.com.

The furin-cleavable consensus sequence at the B-chain/C-peptide;

Forward primer:

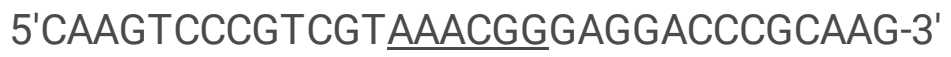

Reverse Primer:

5'GGTGTGTAGAAGAAACCACGTTCCCC-3'

The furin cleavable consensus sequence at the C-peptide/A-chain junction;

Forward primer:

5'GAGGTTGCCCGGLGGAAGCGTGGCATTG 3'.

Reverse primer:

\section{5'CAGTGCCAAGGTCTGAAGATCCC 3'}

After mutation, we had a vector containing the mutated preproinsulin which was ready for transformation to get high yield. For confirmation of the correct insert of the mutated preproinsulin, we amplified the insert using forward and reverse primers containing the site for ligation in the plasmid, purified and desalted. 
Forward primer:

GATCCaccATGGCCCTGTGGATGCGCTTCCTGCCCCTG

Reverse primer:

AATTCGTTGCAGTAGTTCTCCAGTTGGTAGAGGGA

\section{B. Amplification of murine glucose transporter-2 promoter}

The GLUT2 gene is 33,980 bp and its promoter is too long. The more active region in the rat GLUT2 promoter for rat hepatocyte cultureis from -500 to +240 (about 740 bp) (Figure 3). So, this region was amplified by PCR from the extracted rat genomic DNA. PCR primers designed to incorporate appropriate restriction sites at the ends of the target DNA for subsequent digestion and ligation into the vector of choice. The addition of restriction sites by PCR during amplification of a genetic sequence allows for the insertion of virtually any target gene into any vector. Forward primer:

5'CGATAACAATCTTGATTTCCACATCACAAAC-3'

Reverse primer:

5’AGCTTTGCAGGCTGAGGCTGGAGGGAGGCTGGA-3'

\section{Construction of the expressing plasmid}

The expressing plasmid (\#13031) (pcDNA3-EGFP) was received from the Addgene, was ready to be isolated, purified, modified and digested (Figure 4). This plasmid is $6160 \mathrm{bp}$, has an EGFP (enhanced green fluorescent protein) was ready to be fused to the preproinsulin insert to detect the inserted gene location by its green fluorescent appearance. The plasmid DNA was isolated from bacteria, purified to be digested for the insertion process. The digestion happened to the purified plasmid by ECORI and BamHI restriction enzymes, then purified and desalted by using purification kit (Qiaex II Extraction Kit \#20021), then the ligation step for the purified plasmid and the designed mutated preproinsulin gene proceeded. The resulting ligated plasmid was also digested by Nrul and HindIII restriction enzymes, for the GLUT2 promoter ligation. So, we had a new construct of pcDNA3-GLUT2-mutated preproinsulin-EGFP ready to measure by UV spectrophotometer and transfected into cells.

\section{Primary culture of rat hepatic cells}

According to Wan, Kate \& David. 2010, with some modifications, rat hepatic cells were purchased from cell biologics, shipped in suspension (catalog no.RA-6224F). Cells expanded on multi well culture plates ready for experiments under the cell culture conditions specified by Cell Biologics. 
The plateable cells were derived from single donors. Viabilities $>75 \%$. Centrifuged and Suspended the cells in $30 \mathrm{ml}$ warm William's complete Medium supplied with L-glutamine, fetal calf serum, dexamethasone, cadmeium chloride, DMSO, penicillin and streptomycin , then centrifuged and resuspended again in $20 \mathrm{ml}$ warm William's complete Medium. Counted the cells within the cell suspension using a hemocytometer and determined cell viability by trypan blue staining.Plate cells at a collagen coated plates, Cultured at $37^{\circ} \mathrm{C}$ in a humidified atmosphere. After $4 \mathrm{~h}$ culture, the cells could either remained in the same serum-containing medium or replaced the medium with serum-free medium, HepatoZYME-SFM . Replaced the growth medium at 2-day intervals, if needed (Wan, Kate \& David, 2010). After the hepatocyte culture condition was optimized, examined the cells every day under inverted microscope to detect the hepatocyte viability, division and morphology. Imaged every $2 \mathrm{~h}$ in the first day of culture and every day using (Olympus inverted microscope). After optimization the cell culture condition, transfection takes place using $2 \mu$ turbofect transfection reagent (\# R0531) in $1 \mathrm{ml}$ culture medium after $24 \mathrm{~h}$ of culture.

\section{E. Examination after transfection under inverted green fluorescent microscope}

After the transfection, the cells were examined under Olympus inverted microscope, the transfected cells appeared in green fluorescent color.

\section{F. Examination the expressed fused protein}

The transfected hepatocytes were exposed to different concentrations of glucose (from free to $25 \mathrm{mM}$ glucose), analyze the amount of glucose transported into and out the cells in cell lysates and media by glucose colorimetric assay method (Glucose (GO) Assay Kit \#GAGO-20). For the measurements of amount of insulin released against the different concentration of glucose added, we used also the same cell lysate and media from each separate concentration of glucose to measure by cohesion Rat Insulin ELISA Kit \#CEK1622.

\section{G. Sequencing}

The PCR products and plasmid construct were sequenced by the using of ABI prism Big Dye Terminator Cycle Sequencing Ready Reaction Kit (Applied Biosystems, Germany).

\section{lii. Results}

To get the rat preproinsulin, I extracted the genomic rat DNA from the spleen, liver and pancreas. Then, I ran about $10 \mu \mathrm{l}$ from the extracted genomic DNA from different tissues to obtain the perfect one, as shown in Figure 5. 
The genomic DNA extracted from rat liver showed a good band after running on $1 \%$ agarose. Then, I amplified the rat preproinsulin gene from the rat liver genomic DNA by PCR amplification technique using the specific primer designed for rat preproinsulin gene. The amplified PCR product was run on $1 \%$ agarose to indicate the gene size band (about $333 \mathrm{bp}$ ). The amplified product was also sequenced to confirm the sequence for the preproinsulin gene (Figure 6).

The amplified preproinsulin gene was inserted into the linearized cloning vector NEB\#1202 to be ready for the mutation step. Mutation proceeded by using the designed primers for mutation in the two chains. After mutation, I plated the resulting vector on xgal and iptg selection plates to determine which colonies contain the mutation by the white and blue colonies. Then amplified the mutated preproinsulin, inserted into the vector, I ran sequencing to be sure that preproinsulin had mutated perfectly. Next, from the genomic DNA, I also amplified the more active region in glucose transporter-2(GLUT2) promoter for the hepatocyte culture, and inserted it into the vector. Thus, I obtained a vector containing the mutated preproinsulin gene derived by the GLUT2 promoter which I inserted (PCDNA3-GLUT2-mutated preproinsulin-EGFP). This vector concentration was measured to detect its purity (Table 1), and sequenced for both forward and reverse sequence to be sure from the location of the promoter and the inserted gene.

The plasmid was ready to transfect into the primary rat hepatic cells. Primary rat hepatocytes washed, diluted, counted (Figure 7 and Table 2), then cultured in 12 well coated collagen plates with complete Williams E medium in a humified atmosphere incubator for $4 \mathrm{~h}$, and after that, the medium was replaced by hepatozyme, a serum free medium to demonstrate the morphology of the cells (Figure 8 ).

The rat hepatic cells were investigated after plating under the inverted microscope every $24 \mathrm{~h}$ to detect the cell viability, division and morphology (Figure 9, Figure 10 and Figure 11).

After optimization the cell culture conditions, transfection taked place using $2 \mu$ turbofect transfection reagent in $1 \mathrm{ml}$ culture medium, then added $0.5 \mu \mathrm{l}$ from the prepared expressing plasmid and let for $7 \mathrm{~h}$ inside the incubator. Next, started to examine the cell morphology and viability after transfection, analyze the expression of the fluorescent fused protein by visualization under inverted green fluorescent microscope. Although the GLUT2 promoter is a weaker promoter than others, the rat hepatocytes transfected with a construct controlled by this promoter could not live longer than the healthy cells (Figure 12 and Figure 13).

I examined the released fused protein under the green fluorescent protein using PCDNA3-GLUT2-mutated proinsulin-EGFP in both media and inside the cell under the inverted green fluorescent microscope, and I examined the transfected rat hepatocytes with PCDNA3-GLUT2-mutatedpreproinsulin-EGFP and its media in case of stimulation with free glucose and different amount of glucose $(5 \mathrm{mM}, 10 \mathrm{mM}, 15 \mathrm{mM}$ and 25 $\mathrm{mM}$ ). In stimulation with glucose, the green fused protein cross the cell membrane out to the media relating to the amount of glucose found (Figure 14). 
In case of addition of $5 \mathrm{mM}, 15 \mathrm{mM}, 25 \mathrm{mM}$ glucose to the media, the cells increased the transport of glucose gradually, as the strongest action of GLUT2 promoter was in case of using $25 \mathrm{mM}$ glucose (Figure 15, Figure 16 and Figure 17).

Glucose was measured in cell lysates and cell media of transfected culture cells three times and obtained the average, after different concentrations of glucose $(0-25 \mathrm{mM})$ were added to the media by colorimetric glucose assay (Table 3).

Due to the amount of glucose regulated and released, the insulin also released from the construct: PCDNA3-GLUT2-mutated preproinsulin-EGFP. So, I measured the amount of insulin released from this construct three times and obtained the average to balance the amount of glucose found (Figure 18 and Figure 19).

\section{Iv Discussion}

Proinsulin is transported in micro vesicles to the Golgi apparatus, where it is packaged into membranebound vesicles known as secretory granules. Prohormone convertases 2 and 3 are responsible for the conversion from proinsulin to mature insulin, which remove the $\mathrm{C}$ peptide chain, liberating two cleavage dipeptides and finally yielding insulin. When I generated a furin cleavable site inside the preproinsulin gene inside the designing cassette to obtain insulin, it worked well as these cleavable sites do the action of PC1 and PC2 to remove the C-peptide and convert the immature insulin to a mature one.

GLUT2 is a transmembrane protein that enables glucose transport across cell membranes. GLUT2 and glucokinase have been dubbed the "glucose sensors" of $\beta$ cells because they enable $\beta$ cells to sense glucose over a very broad range of concentrations (Newgard and McGarry, 1995; Won, Rhee and Ko, 2009). In our studies, GLUT2 showed its ability to sense glucose and to transport it into and out the cells. The present study was designed to investigate the relation between glucose and insulin and how they gather to make the balance inside and outside the cells, as there was a large amount of glucose outside the cells, the GLUT2 absorbs some of it inside the cells to make balance. Therefore, a certain amount of insulin is secreted according to the amount of glucose found. The obtained insulin secretion in our results derived by the GLUT2 promoter is much better than that derived by strong promoter (Won, Rhee and Ko, 2009; Andrew et al., 2016).

Insulin can be secreted from hepatocytes by performing some modifications to the preproinsulin gene to cleave correctly inside the hepatocytes and by activation a certain region in the glucose transporter-2 promoter in hepatocytes to sense and transport glucose. Hepatocytes are easily obtained, but must be engineered with a processing mechanism and a regulatory secretion system (Kahn \& Weir, 1994). Rat hepatocyte is a good target to express insulin due to the presence of the GLUT2 gene which plays a perfect role to modulate glucose level (Hovorka, 2011; Vehik et al., 2013). Although adult hepatocytes have a remarkable ability to proliferate in vivo, attempts to proliferate adult hepatocytes in vitro have been less successful (Overturf et al., 1997; Taub, 2014); these result are similar to our results as the count 
number of primary rat hepatocytes decreased every day till cell death. Thus, the primary hepatocytes could not divide well in vitro.

In my results, I supplemented the media of primary rat hepatocytes culture with insulin and dexamethasone to make the cells live longer. The supplementation of the media with hormones, such as dexamethasone and insulin, has greatly enhanced the attachment efficiency of hepatocytes and prolonged the hepatocyte survival to a certain extent (Bissell, Hammaker \& Meyer, 1973; Michalopoulos \& Pitot, 1975; Miyazaki et al., 1978)

A point of interest is that the use of a non-viral vehicle cassette is shown to be more efficient in in-vitro studies and safer when treating the sensitive primary rat hepatocytes (Duckworth, Bennett \& Hamel, 1998). SuperFect Transfection Reagent, TurboFect, Lipofectamine, Effectene Transfection Reagent and Tfx-20 were the most effective for the transfection of primary hepatocytes and give comparable transfection efficiencies (Tang, Redemann \& Szoka, 1996; Mosher \& Crews, 1999;). Similar results have been reported in our findings using the turbofect transfection reagent.

\section{Vi Conclusion}

The current study aimed to produce insulin from other organs of the body by using a construction of the mutated rat proinsulin CDNA regulated by rat GLUT2 promoter transfected into hepatocyte cells cultured from rats to produce mature insulin as a strategy to modulate glucose level after exposing the cells to different concentrations of glucose and measuring the amount of glucose consumed by the cells and the insulin amount produced.

\section{List Of Abbreviations}

GLUT 2 Glucose transporter 2

DM Diabetes Mellitus

FCS Furin Cleavable Sites

EGFP Enhanced Green Fluorescent Protein

PCR Polymerase Chain Reaction

FP Forward Primer

RP Reverse Primer

\section{Declarations}

Acknowledgment 
I am deeply grateful to my mother, brother and my husband who encouraged and supported me. Thanks also go to the Research and Medical Technology Institute, Alexandria, Egypt, to the research lab in the Faculty of Medicine, Alexandria, Egypt, and to Dr. Necholas J. Lees-Gayed.

\section{Ethics declarations}

\section{Ethics approval and consent to participate}

The experiments were approved by the Medical Researches and Technology Institute, by the Faculty of Science, and by the genetic lab in Faculty of Medicine, Alexandria, Egypt.

\section{Competing interests}

I declare no conflict of interest.

\section{Funding}

This study was supported by my self.

\section{Availability of data and materials}

The data generated and/or analyzed during the current study are available from the corresponding author upon request.

\section{Author Contributions}

Prof. Dr. Necholas J. contributed to get final results in the part of culture preparations, the Lab Specialist Karim M. contributed to get the final results for glucose concentrations and helping in the capture of fluorescent images and Eng. Mohammed E. helped to get the final curves for insulin.

\section{References}

Ahn YH, Kim JW, Han GS, Lee BG and Kim YS. 1995. Cloning and characterization of rat pancreatic beta cell/liver type glucose transporter gene: A unique exon/entron organization. Archieves of biochemistry and biophysics, 323(2): 387-396.

Andrew MH, Hans WS and Tausif A. 2016. Modern Tools for Genetic Engineering. -In: Insulin Gene Therapy for Type 1 Diabetes Mellitus:Unique Challenges Require Innovative Solutions, University of Wisconsin, Madison, USA.

Ashcroft S, Bunce J, Lowry M, Hansen S and Hedeskov C. 1978. The effect of sugars on (pro)insulin biosynthesis. Biochemical Journal, 174(2): 517-526. 
Barcinski M and Rosenthal A. 1977. Immune response gene control of determinant selection. I. Intramolecular mapping of the immunogenic sites on insulin recognized by guinea pig $T$ and $B$ cells. Journal of Experimental Medicine, 145(3): 726-742.

Bissell D, Hammaker L and Meyer U. 1973. Parenchymal cells from adult rat liver in non proliferating monolayer culture. Journal of Cell Biology, 59(3): 722-734.

Burkhardt B, Parker M, Zhang Y, Song S, Wasserfall C and Atkinson M. 2005. Glucose transporter-2 (GLUT2) promoter mediated transgenic insulin production reduces hyperglycemia in diabetic mice. FEBS Letters, 579(25): 5759-5764.

Docherty K. 1997. Gene Therapy for Diabetes Mellitus. Clinical Science, 92(4): 321-330.

Duckworth W, Bennett R and Hamel F. 1998. Insulin Degradation: Progress and Potential. Endocrine Reviews, 19(5): 608-624.

Harris MI and Zimmet P. 1985. International Textbook of Diabetes Mellitus. -In: 2nd ed., Classification of diabetes mellitus and other categories of glucose intolerance, International Diabetes Institute, Melbourne, Victoria, Australia.

Hohmeier H, BeltrandelRio H, Clark S, Henkel-Rieger R, Normington K. and Newgard C. 1997. Regulation of insulin secretion from novel engineered insulinoma cell lines. Diabetes, 46(6): 968-977.

Hovorka R. 2011. Closed-loop insulin delivery: from bench to clinical practice. Nature Reviews Endocrinology, 7(7): 385-395.

Jefferson D, Clayton D, Darnell J and Reid L. 1984. Posttranscriptional modulation of gene expression in cultured rat hepatocytes. Molecular and Cellular Biology, 4(9): 1929-1934.

Kahn CR, Weir GC. 1994. Principles of insulin therapy. Joslin's Diabetes Mellitus, 6: 460-488.

Lu D, Tamemoto H, Shibata H. Saito I and Takeuchi T. 1998. Regulatable production of insulin from primary-cultured hepatocytes: insulin production is up-regulated by glucagon and cAMP and downregulated by insulin. Gene Therapy, 5(7): 888-895.

Meslier N, Gagnadoux F, Giraud P Person H, Ouksel T, Urban JL and Racineux. 2003. Impaired glucoseinsulin metabolism in males with obstructive sleepapnoea syndrome. Eur Respir J, 22 (1): 156-160.

Michalopoulos $\mathrm{G}$ and Pitot $\mathrm{H}$. 1975. Primary culture of parenchymal liver cells on collagen membranes. Experimental Cell Research, 94(1): 70-78.

Mitchell P and Tjian R. 1989. Transcriptional regulation in mammalian cells by sequence-specific DNA binding proteins. Science, 245(4916): 371-378. 
Miyazaki M, Watanabe A, Shiraishi M, Hoshika T, Miyano K and Sato J. 1978. Primary culture of adult rat liver cells. Acta med okayama, 32(2): 85-96.

Mosher JT and Crews ST. 1999. Effectene Reagent yields high transfection efficiencies with Drosophila melanogaster S2 cells. Qiagen News, 4: 7-13.

Neuberg M, Adamkiewicz J, Hunter JB and Muller R. 1989. A Fos protein containing the Jun leucine zipper forms a homodimer which binds to the AP1 binding site. Nature, 341(6239): 243-245.

Newgard CB and McGarry JD. 1995. Metabolic coupling factors in pancreatic beta-cell signal transduction. Annu Rev Biochem, 64: 689-719.

Nett P, Hans WS and Tausif A. 2003. Hepatic insulin gene therapy in insulin-dependent diabetes mellitus. American Journal of Transplantation, 11: 1197-1203.

Orci L, Ravazzola M, Storch M, Anderson R, Vassalli J and Perrelet A. 1987. Proteolytic maturation of insulin is a post-Golgi event which occurs in acidifying clathrin-coated secretory vesicles. Cell, 49(6): 865868.

Overturf K, al Dhalimy M, Ou C, Finegold M, Grompe M. 1997. Serial transplantation reveals the stem cell like regenerative potential of adult mouse hepatocytes. Am J Pathol, 151(5): 1273-1280.

Schwartz TW.1990. Molecular Biology of the Islet of Langerhans. -In: H.Okamoto ed., Cambridge University Press, Cambridge, UK, P. 153-205.

Selden RF, Skoskiewicz MJ, Russell PS and Goodman HM. 1987. Implications for genetherapy: Regulation of insulin gene expression. New Engl J Med, 317(17): 1067-1076.

Tang MX, Redemann CT and Szoka FC.1996. In vitro gene delivery by degraded poly amido amin dendrimers. National lib Med, 7(6): 703-714.

Taub R. 2014. Liver regeneration: From myth to mechanism. Nat Rev Mol Cell Biol., 5(10): 836-847.

Tuch BE, Szymanska B,Yao M, Tabiin MT, Gross DJ, Holman S, Anne Swan M, Humphrey RK, Marshall GM and Simpson AM. 2003. Function of a genetically modified human liver cell line that stores, processes and secretes insulin. Gene Ther, 10(6): 490-503.

Vehik K, Ajami NJ, Hadley D, Petrosino JF and Burkhardt BR. 2013. The changing landscape of type 1 diabetes: recent developments and future frontiers. Current Diabetes Reports, 13(5): 642-50.

Wan L, Kate R and David T.2010. Mouse cell culture Methods in molecular biology : Isolation and culture of adult mouse hepatocytes. 633: 185-196.

Won JC, Rhee BD and Ko KS. 2009. Glucose-responsive gene expression system for gene therapy. Adv Drug Deliv Rev, 61: 633-640. 
World Health Organization (WHO). 1999. Definition, diagnosis and classification of diabetes mellitus and its complications. -In: report of a WHO consultation. Part 1, Diagnosis and classification of diabetes mellitus, World Health Organization, Geneva.

\section{Tables}

\section{Table 1}

Measuring the concentration and the purity of the extracted plasmid using UV spectrophotometer (the dilution factor was X300).

\begin{tabular}{|lllll|}
\hline Plasmid & A260 & A280 & Concentration $(\mu \mathrm{g} / \mathrm{ml})$ & Ratio \\
\hline PCDNA3-GLUT2-mutated preproinsulin - EGFP & 0.258 & 0.143 & 3870 & 1.8 \\
\hline
\end{tabular}

\section{Table 2}

The count of live and dead cells on haemocytometer to detect the viability and cell density of the rat hepatic cells. Viable cells $=71.5 \times 10^{4} \times 2=143 \times 10^{4}$ cells $/ \mathrm{ml}$. Total count $=75.5 \times 10^{4} \times 2=151 \times 10^{4}$ cells/ml.

Viability $\%=$ viable/total $=143 / 151=95 \%$

Cell density $=$ total count

\begin{tabular}{|llll|}
\hline \# of square & Live cells & Dead cells & Total count \\
\hline 1 & 75 & 0 & 75 \\
\hline 2 & 62 & 7 & 69 \\
\hline 3 & 91 & 3 & 94 \\
\hline 4 & 58 & 6 & 64 \\
\hline Average & 71.5 & 4 & 75.5 \\
\hline
\end{tabular}

\section{Table 3}

The colorimetric glucose assay method for the detection the amount of glucose present in both cell media and lysates after the addition of different amount concentration of glucose to the media of transfected cells. This method shows how the cells can consume the amount of outer glucose in the 
media to cross the cell membrane. The GLUT2 promoter construct has the ability to transport the glucose in and out the cells, as this promoter is glucose transporter and regulator for the amount of glucose.

\begin{tabular}{|c|c|c|c|c|c|c|}
\hline \multirow[b]{2}{*}{$\begin{array}{l}\text { Different doses of } \\
\text { glucose added in } \mathrm{mM}\end{array}$} & \multicolumn{6}{|c|}{$\begin{array}{l}\text { Calorimetric glucose assay in } \mathrm{mg} / \mathrm{dl} \text { after } 24 \mathrm{~h} \text { from the addition of different } \\
\text { doses of glucose in the transfected primary hepatocyte culture medium }\end{array}$} \\
\hline & & Free glucose & $5 \mathrm{mM}$ & $10 \mathrm{mM}$ & $15 \mathrm{mM}$ & $25 \mathrm{mM}$ \\
\hline \multirow{3}{*}{$\begin{array}{l}\text { PCDNA3-GLUT2- } \\
\text { Mutated } \\
\text { preproinsulin-EGFP }\end{array}$} & In media & ND & 85 & 102 & 136 & 150 \\
\hline & In & ND & 69 & 70 & 71 & 83 \\
\hline & Cell lysate & & & & & \\
\hline
\end{tabular}

\section{Figures}

ATGGCCCTGTGGATGCGCTTCCTGCCCCTGCTGGCCCTGCTCG TCCTCTGGGAGCCCAAGCCTGCCCAGGCTTTTGTCAAACAGCACCT TTGTGGTCCTCACCTGGTGGAGGCTCTGTACCTGGTGTGTGGGGAA CGTGGTTTCTTCTACACACCCAAGTCCCGTCGTGAAGTGGAGGACC CGCAAGTGCCACAACTGGAGCTGGGTGGAGGCCCGGAGGCCGGGG ATCTTCAGACCTTGGCACTGGAGGTTGCCCGGCAGAAGCGTGGCAT TGTGGATCAGTGCTGCACCAGCATCTGCTCCCTCTACCAACTGGAG AACTACTGCAACTGA

Figure 1

Wild type insulin gene sequences.
ATGGCCCTGTGGATGCGCTTCCTGCCCCTGCTGGCCCTGCTCG TCCTCTGGGAGCCCAAGCCTGCCCAGGCTTTTGTCAAACAGCACCT TTGTGGTCCTCACCTGGTGGAGGCTCTGTACCTGGTGTGTGGGGAA CGTGGTTTCTTCTACACACCCAAGTCCCGTCGTAAACGGGAGGACC CGCAAGTGCCACAACTGGAGCTGGGTGGAGGCCCGGAGGCCGGG ATCTTCAGACCTTGGCACTGGAGGTTGCCCGGCGGAAGCGTGGCA TTGTGGATCAGTGCTGCACCAGCATCTGCTCCCTCTACCAACTGGA GAACTACTGCAACTGAף

Figure 2

Mutant insulin gene sequences. 
-500 to +240 promoter region

TAACAATCTTGATTTCCACATCACAAACGTGCAATTGGACTAGAGG ACCAGAGAGGCCAGGCAGGGGGACCTGACCTTCAGGACGGAGTTC TTCCCGTGAAGAACTTGGTTTTCACTCCTGCCTCTACTCTTATCTGA CTCAACAGGAGAAGAACGCAGCAGGCTTCTCTGAGCTGTTTCCTCT GATTTATAGACAAAACAAAATTTAAAAACCCATTCCTGTAGCTTTG CTAAAAAAAAGACAATGAAGGGGAGAAAGGGAGGCGAGGTTACC ATTTCCGATTCTAGGTGTTTCCTCTCTTAATTAACGATGTAATCAGG ATGTGACCTGAAAGGTTTTAAAGTATAAGGCCAGGTCTATGGAGG ACACCTGCTGGGTCAGAACATTTGCTCTGCAAACACAAGGACCTG AACTCAATCGCTAGTACCCAGTACGGGTTGTGCCTGCATAGAACGG GCACAGGGGCACCGAGGCACCGAGACAGAGGGATCATAATCAGA GCTGGTTTTGCAGTGCAGCAGGAATCTCTGAGTGCTTTTGAGAACT CAGTAGGTAGACGTCATCCCAGGGCAAAGTACAAAGAGCCAGGTT TCCTTGCCAGACATTATCCCACAGAAACCCGCAGCTCCTCTGTGCG CCCTGAAGCCACTGTAGCAGTTTCGCATGAGGTTGGTCTGTGACCT GAATTCACCTGGTAAAATCAGCCTGTGCAATATCCTCCCTCCAGCC TCAGCCTGCA

Figure 3

The sequence for the more active region in rat GLUT2 promoter for rat hepatocyte culture. 


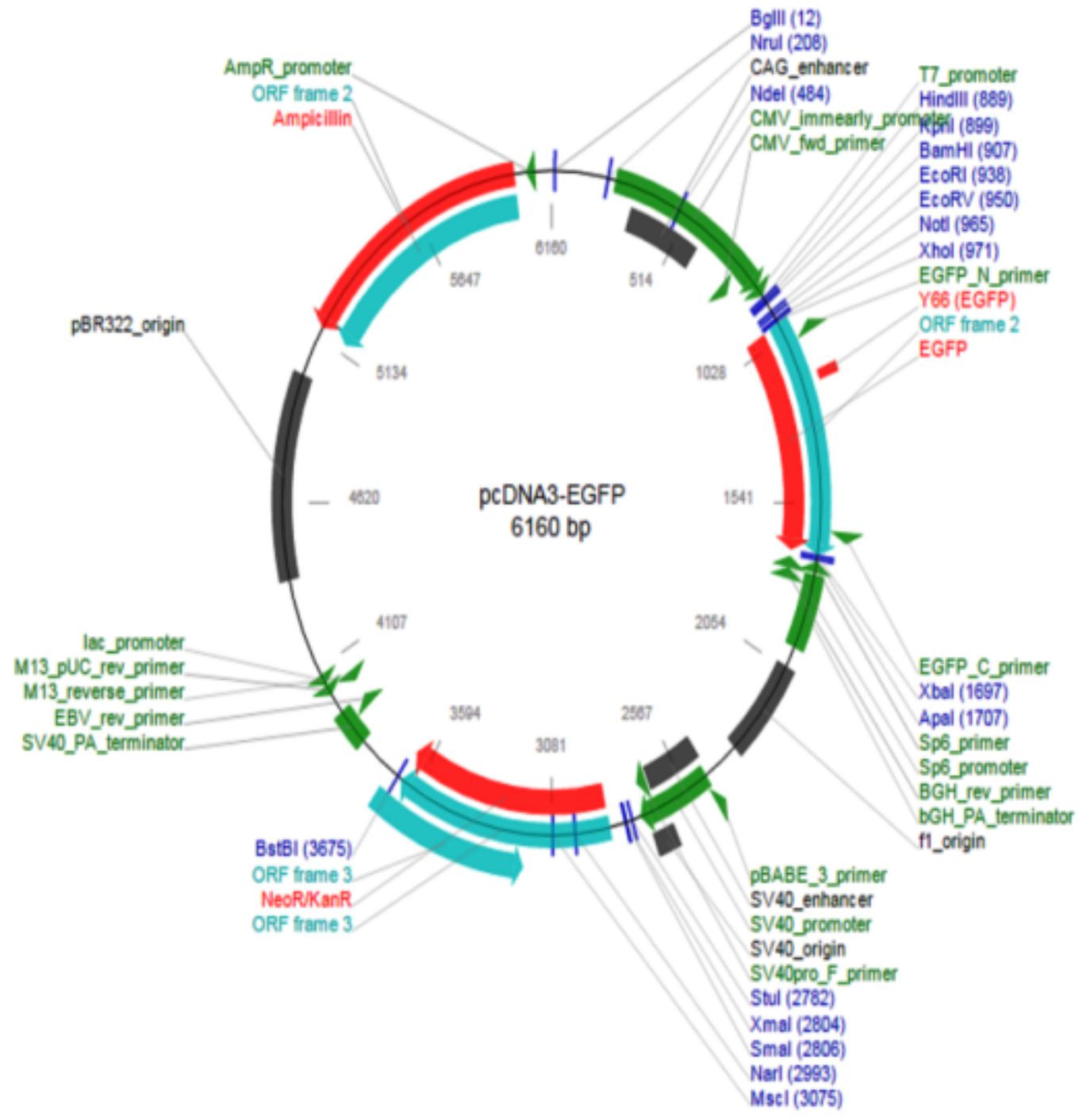

Figure 4

Construction of plasmid \#13031 received from the addgene. 


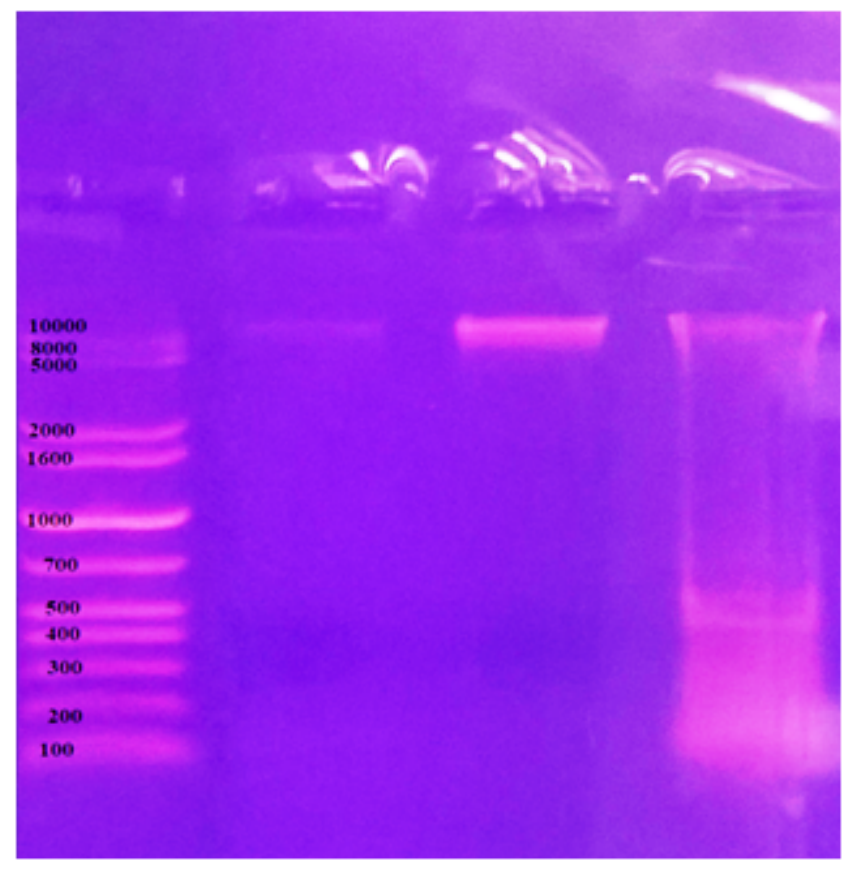

\section{Figure 5}

The genomic DNA extracted from rat. Lane 1: The DNA ladder, lane 2: The DNA extracted from rat spleen, lane 3: The DNA extracted from rat liver, and lane 4: the DNA extracted from rat pancreas.

\section{AACATGGCCCTGIGGATGCGCTICCTGCCCCTGCTGGCCCTGCTCGICCTCTGGGAGCCCAAG \\ 64CCTGCCCAGGCTITTGTCAAACAGCACCTITGIGGICCTCACCTGGIGGAGGCICIGTACCTG \\ 127 GIGTGIGGGGAACGIGGITTCTICTACACACCCAAGTCCCGICGTGAAGIGGAGGACCCGCAA \\ 190 GIGCCACAACTGGAGCTGGGIGGAGGCCCGGAGGCCGGGGATCTTCAGACCTTGGCACTGGAG \\ 253 GITGCCCGGCAGAAGCGTGGCAITGTGGAICAGTGCTGCACCAGCAICTGCTCCCICTACCAA \\ 316 CIGGAGAACTACTGCAAC}

Figure 6

The forward sequence of the amplified PCR product (the rat preproinsulin gene).
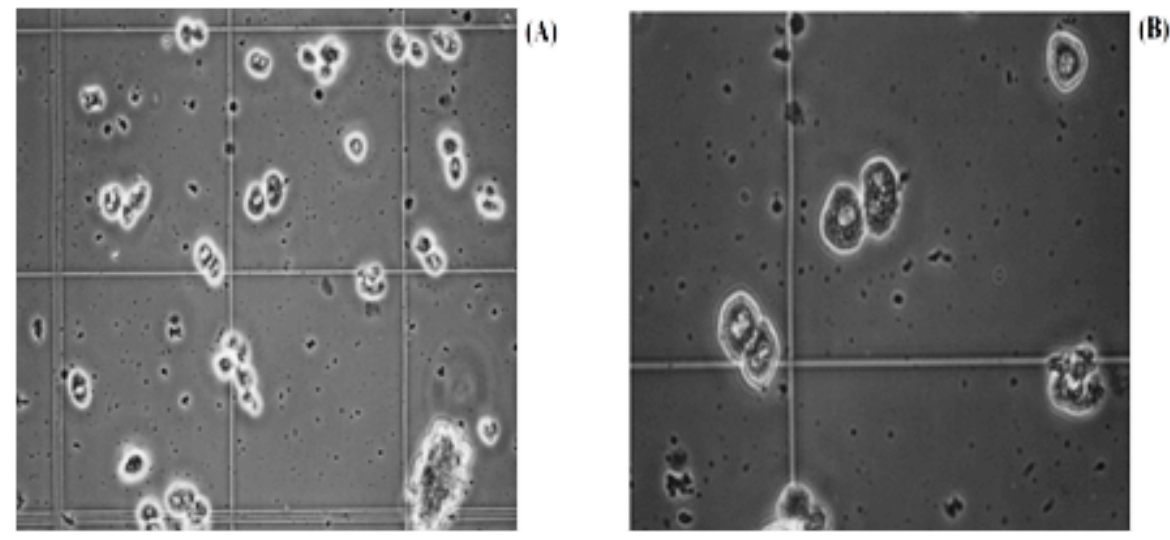


\section{Figure 7}

The count of the rat hepatocytes on haemocytometer using trypan blue under inverted microscope. (A) The rat hepatocytes X100. (B)Tthe rat hepatocytesX200.

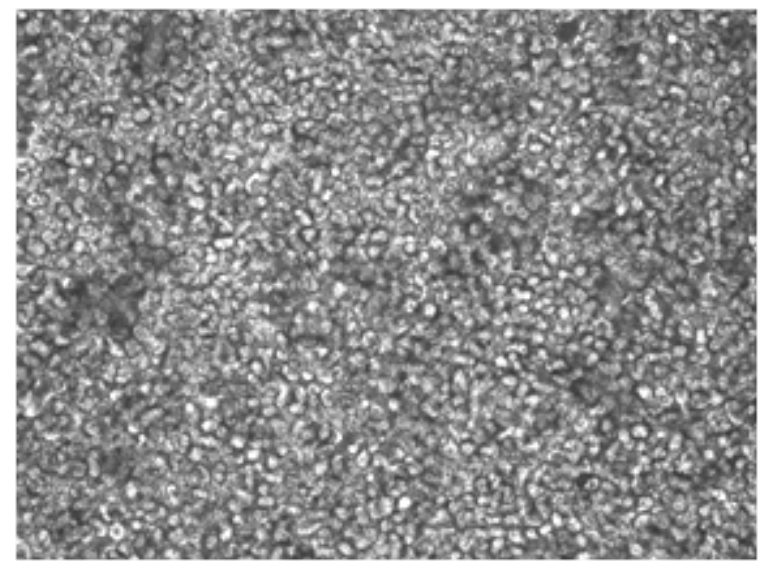

\section{Figure 8}

The rat hepatocytes immediately after plating on a 12-well collagen coated plate with Williams $E$ complete medium under inverted microscope, shows the cells X100. 

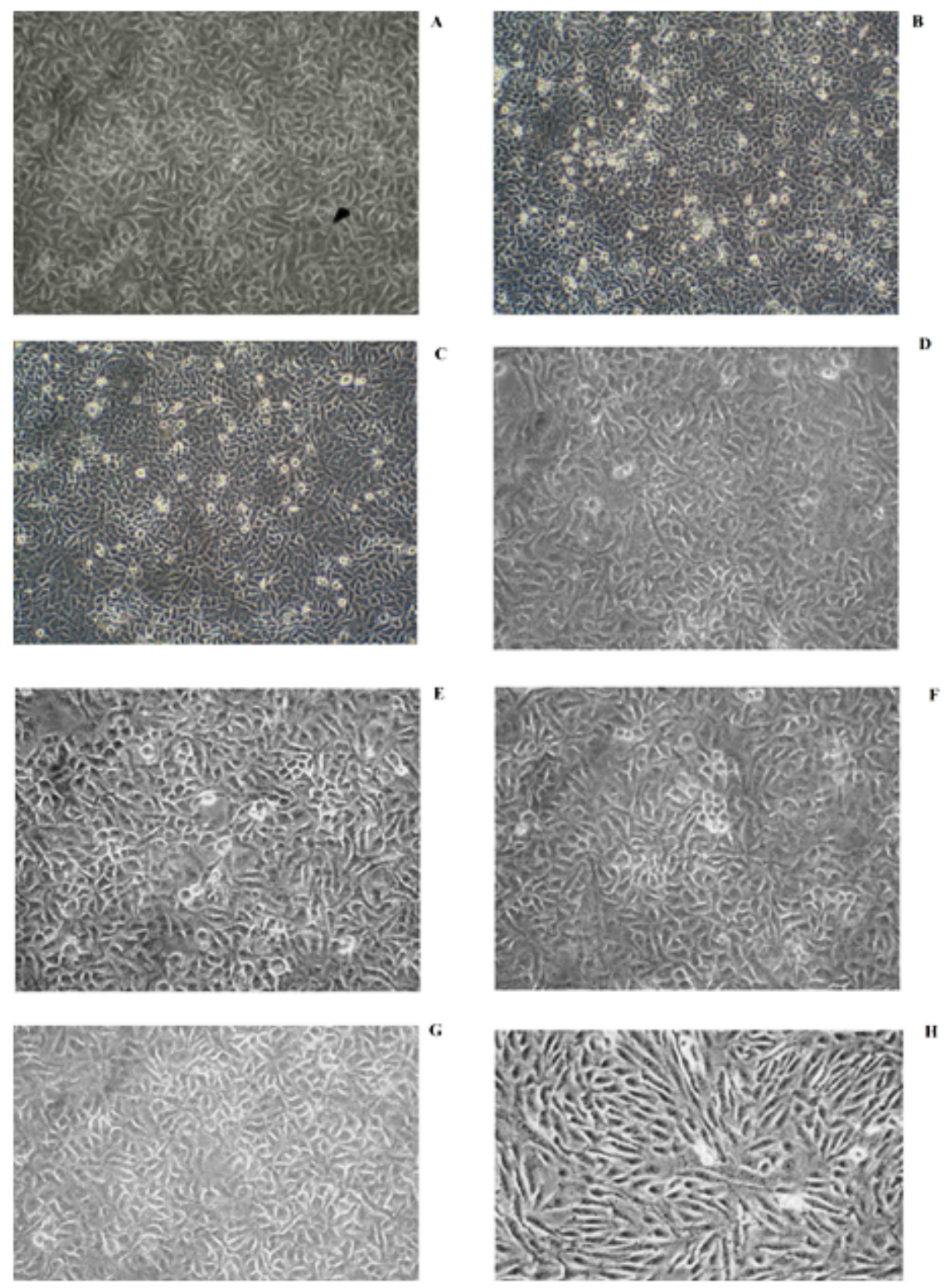

Figure 9

X100 rat hepatic cells after plating. (A) After $24 \mathrm{~h}$ of plating. (B) After $48 \mathrm{~h}$ of plating. (C) After 3 days of plating. (D) After 4 days of plating. (E) After 5 days of plating. (F) After 6 days of plating. (G) After 7 days of plating. $(H)$ After 9 days of plating. 


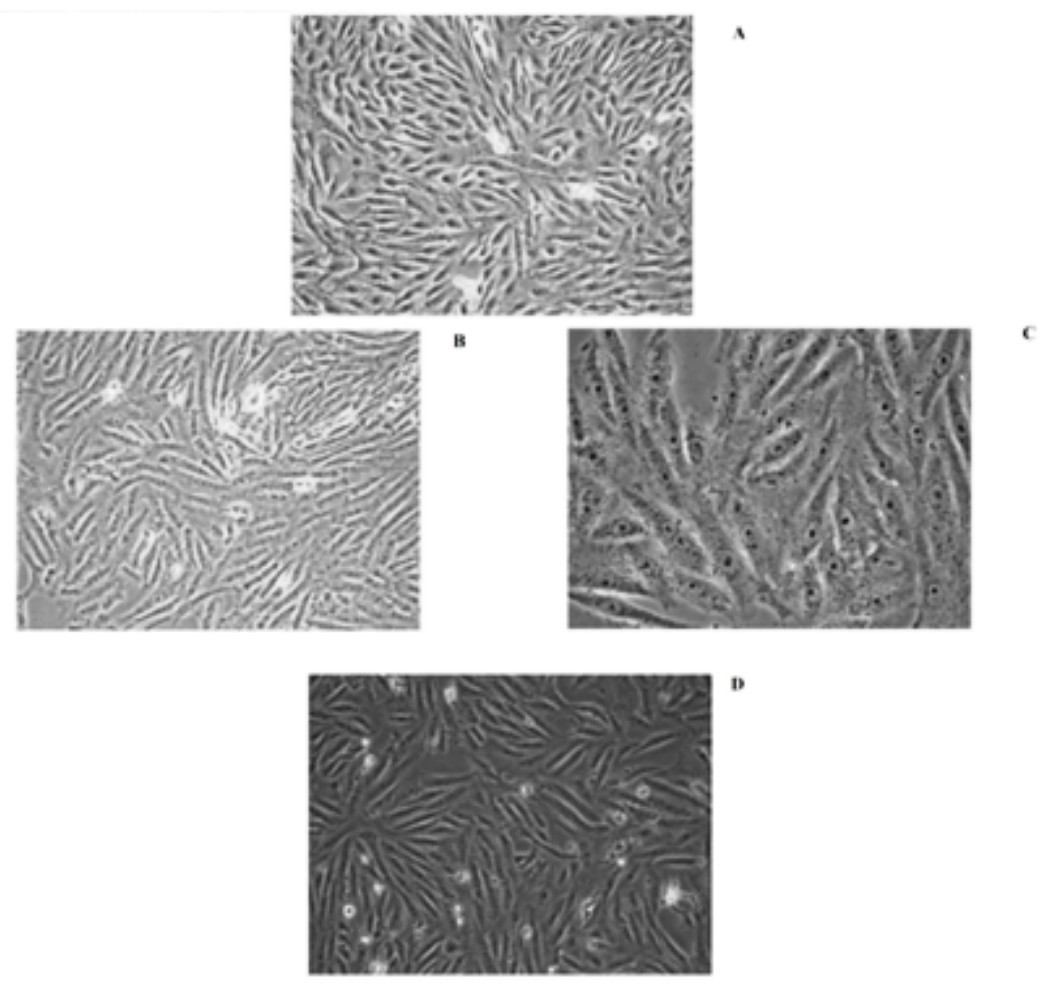

Figure 10

(A)X100 rat hepatic cells after 10 days of plating. (B)X100 rat hepatic cells after 11 days of plating. (C)X200 rat hepatic cells after 11 days of plating. (D)X100 rat hepatic cells after 13 days of plating. 

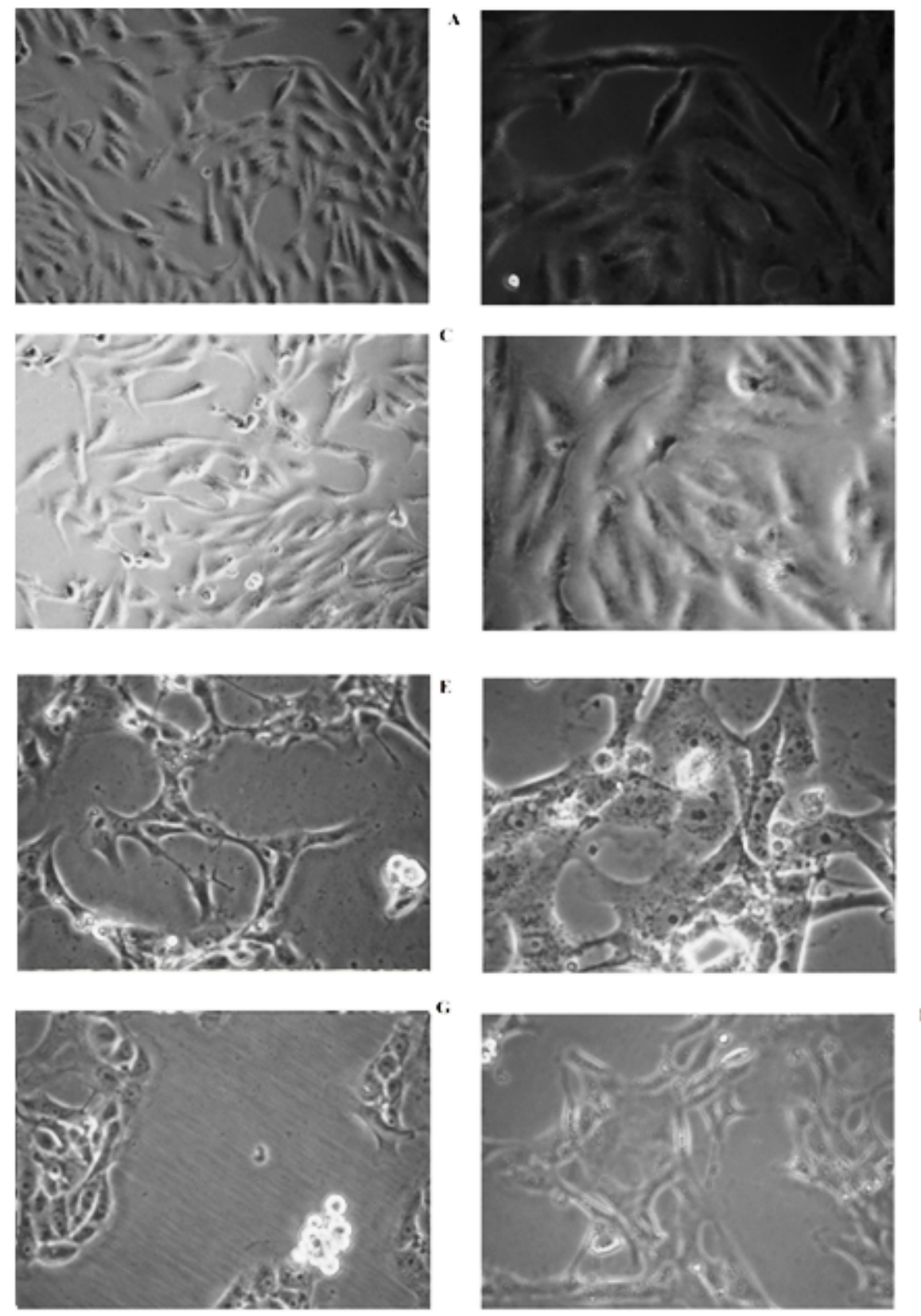

Figure 11

(A)X200 rat hepatic cell after 16 days of plating. (B)X400 rat hepatic cell after 16 days of plating. (C)X200 rat hepatic cell after 17 days of plating. (D)X400 rat hepatic cell after 17 days of plating. (E)X200 rat hepatic cells after 19 days of plating. (F)X400 rat hepatic cells after 19 days of plating. (G)X200 rat hepatic cells after 20 days of plating. $(\mathrm{H}) \mathrm{X} 400$ rat hepatic cells after 20 days of plating 

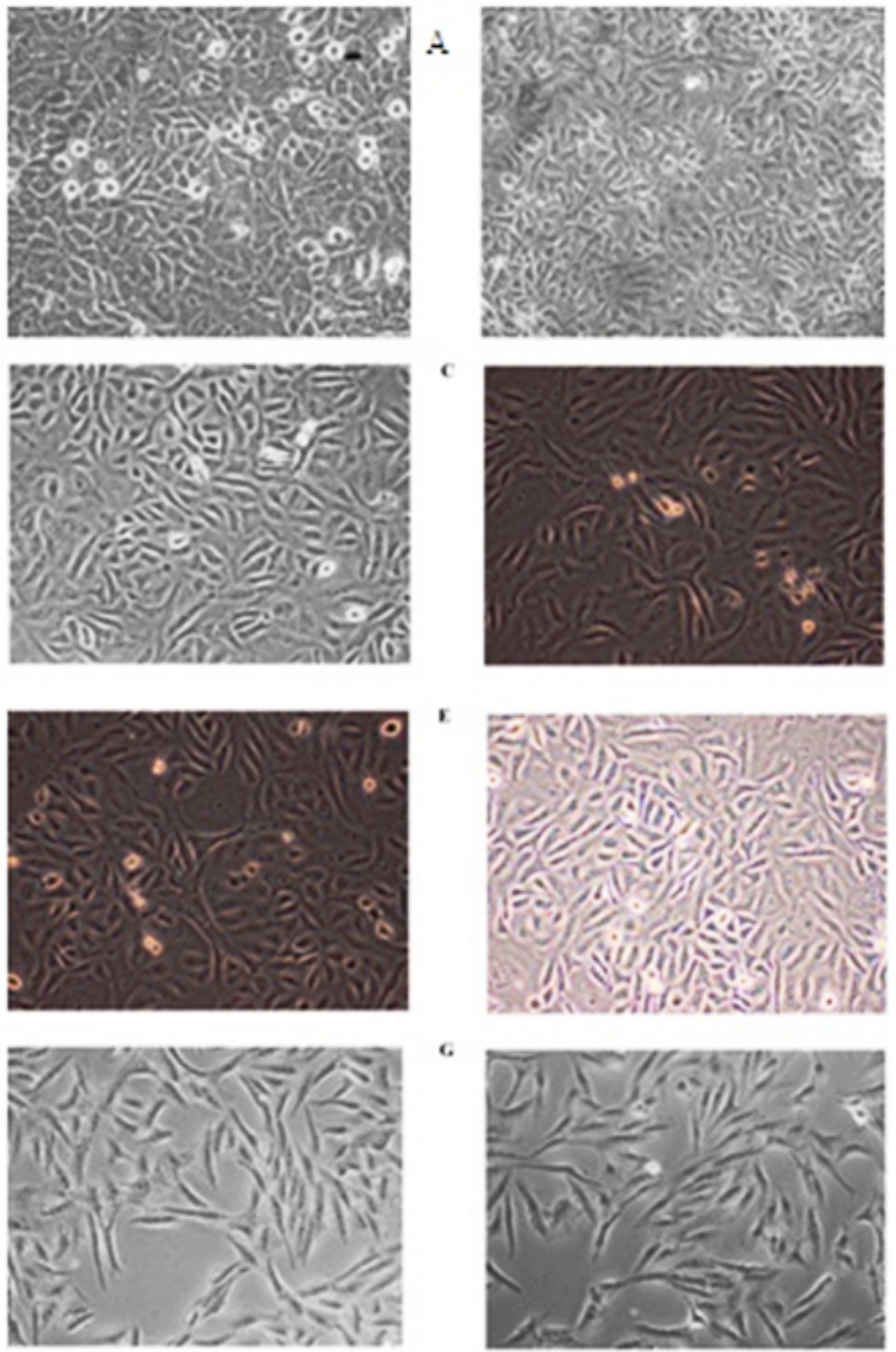

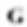
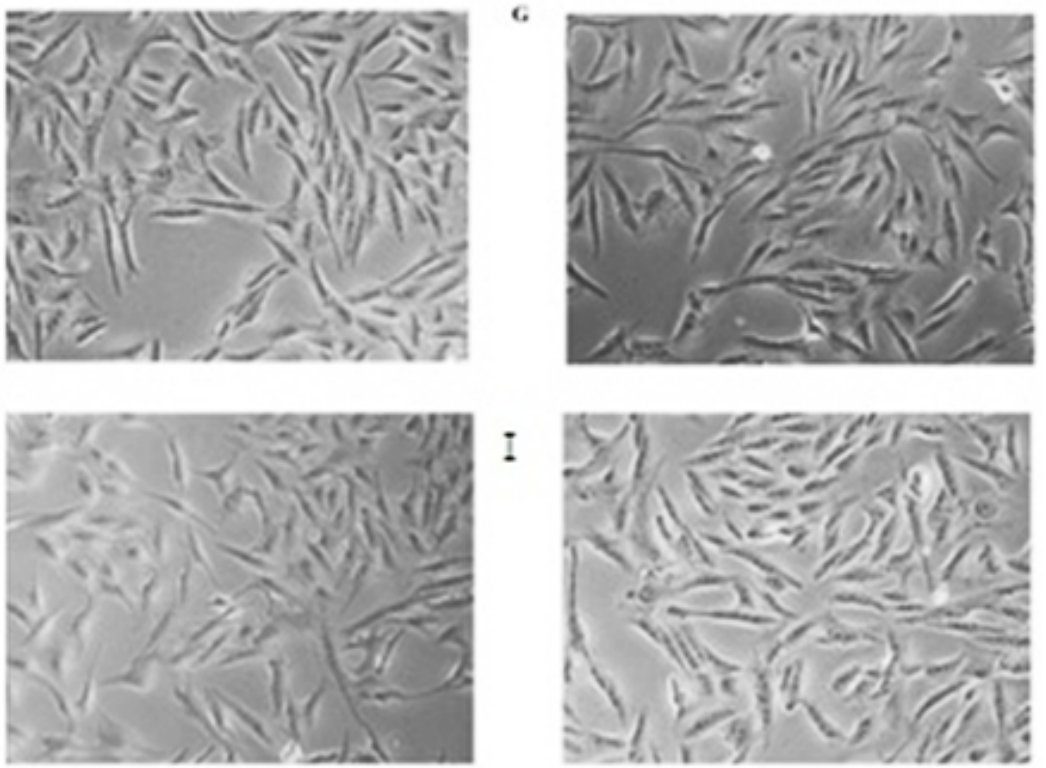

Figure 12

The rat hepatic cells after the transfection with a construct controlled by GLUT2 promoter (PCDNA3GLUT2-mutated preproinsulin- EGFP) X100. (A) The rat hepatocytes after $7 \mathrm{~h}$ from transfection. (B) The rat hepatocytes after $24 \mathrm{~h}$ from transfection. (C) The rat hepatocytes after 2 days from transfection. (D) The rat hepatocytes after 3 days from transfection. $(E)$ The rat hepatocytes after 4 days from transfection. (F) The rat hepatocytes after 5 days from transfection. (G) The rat hepatocytes after 6 days 
from transfection. $(\mathrm{H})$ The rat hepatocytes after 7 days from transfection. (I) The rat hepatocytes after 8 days from transfection. $(\mathrm{J})$ The rat hepatocytes after 9 days from transfection.
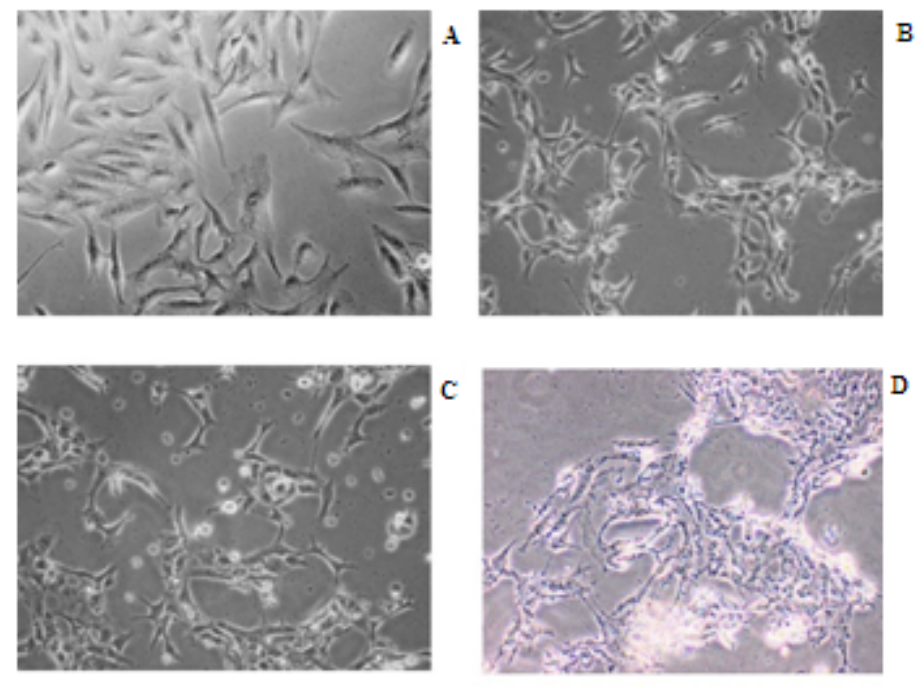

\section{Figure 13}

The rat hepatic cells after transfection with a construct controlled by GLUT2 promoter (PCDNA3-GLUT2 mutated preproinsulin-EGFP) X100. (A) The rat hepatocytes after 10 days from transfection. (B) The rat hepatocytes after 11 days from transfection. (C) The rat hepatocytes after 12 days from transfection. (D) The rat hepatocytes after 13 days from transfection. 

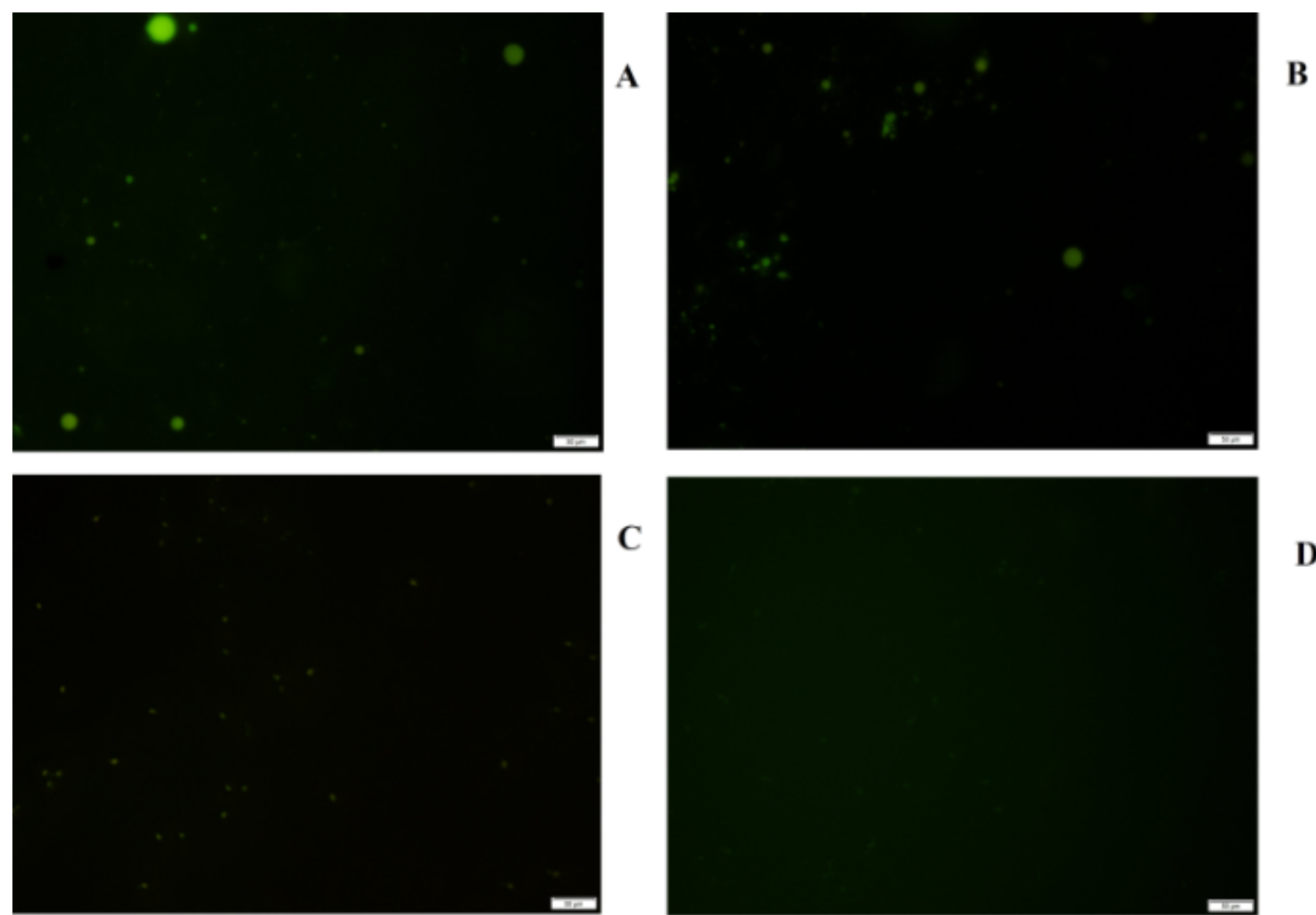

$C$

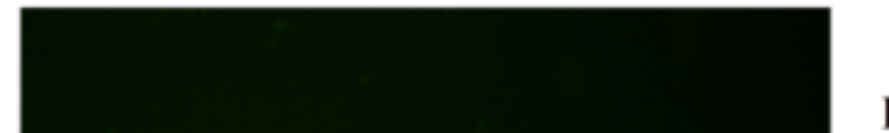

D

\section{Figure 14}

The media of stimulated transfected rat hepatocytes with PCDNA3- GLUT2- mutated preproinsulin- EGFP X100. (A) The media after $24 \mathrm{~h}$ from transfection. (B) The media after 3 days from transfection. (C) The media after 5 days from transfection. (D) The media after 7 days from transfection. (E) The media after 10 days from transfection. (F) The media after 13 days from transfection. 

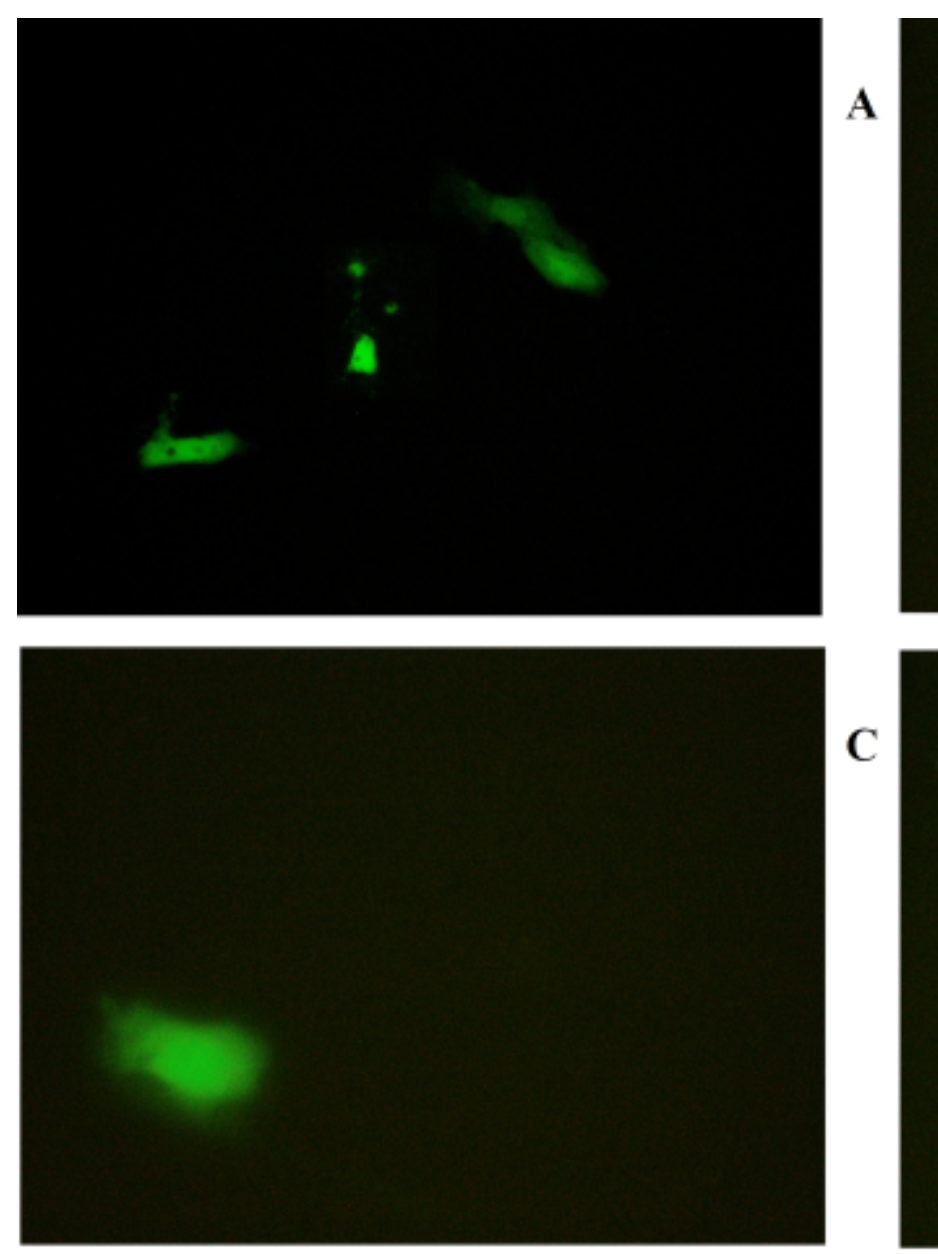

D

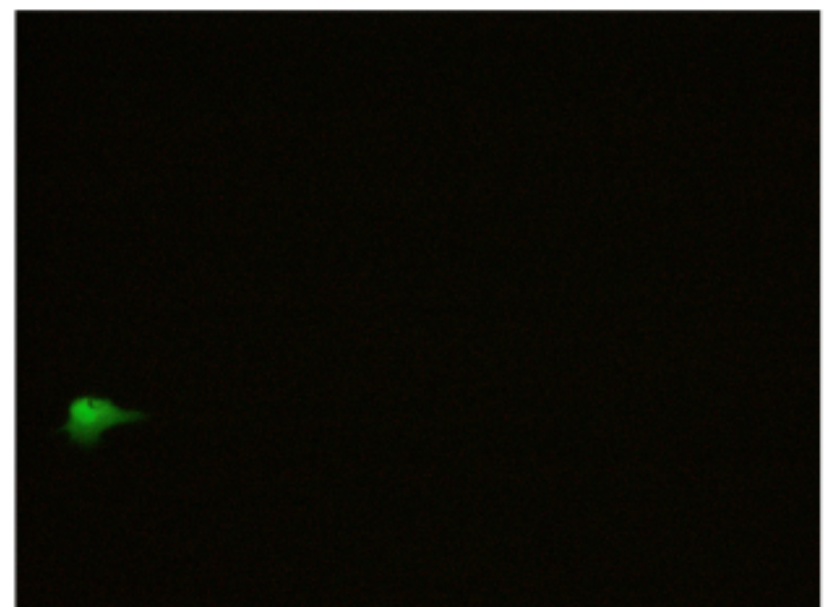

E

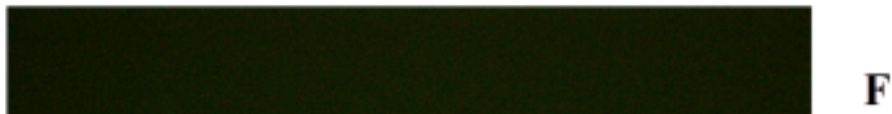

\section{Figure 15}

The transfected rat hepatocytes with PCDNA3-GLUT2-mutated preproinsulin-EGFP when $5 \mathrm{mM}$ glucose added to the media X200. (A) The transfected rat hepatocytes after $24 \mathrm{~h}$ from transfection. (B) The transfected rat hepatocytes after 3 days from transfection. (C) The transfected rat hepatocytes after 5 days from transfection. (D) The transfected rat hepatocytes 7 days from transfection. (E) The transfected rat hepatocytes after 10 days from transfection. (F) The transfected rat hepatocytes after 12 days from transfection. 


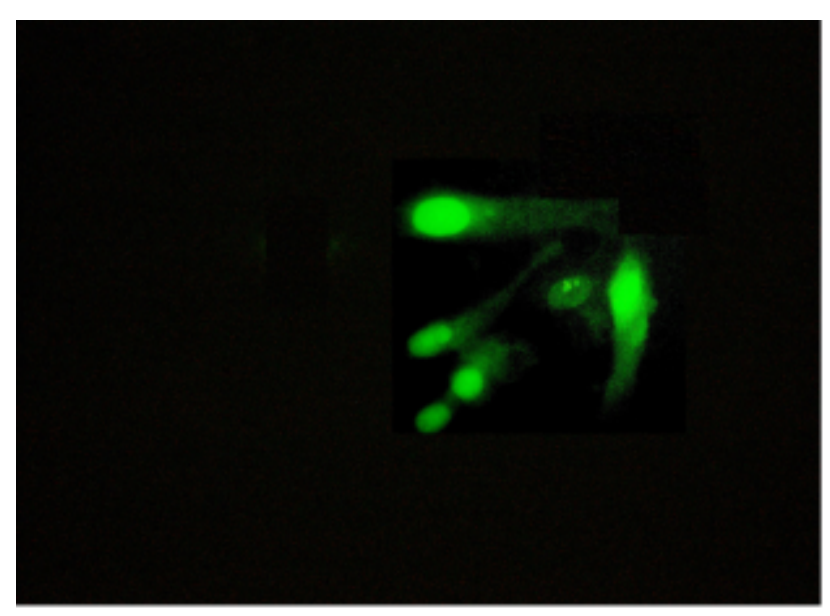

A
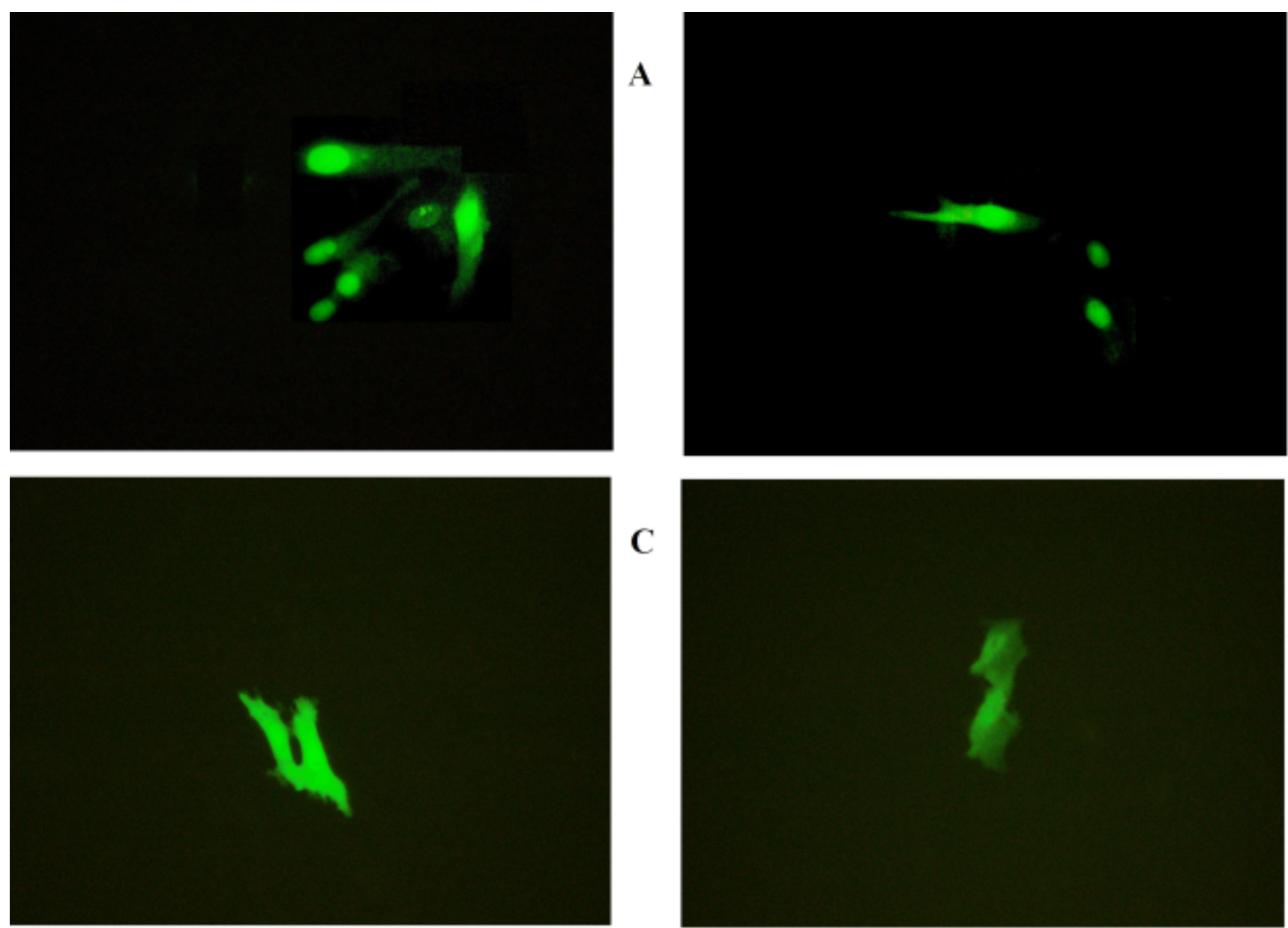

D

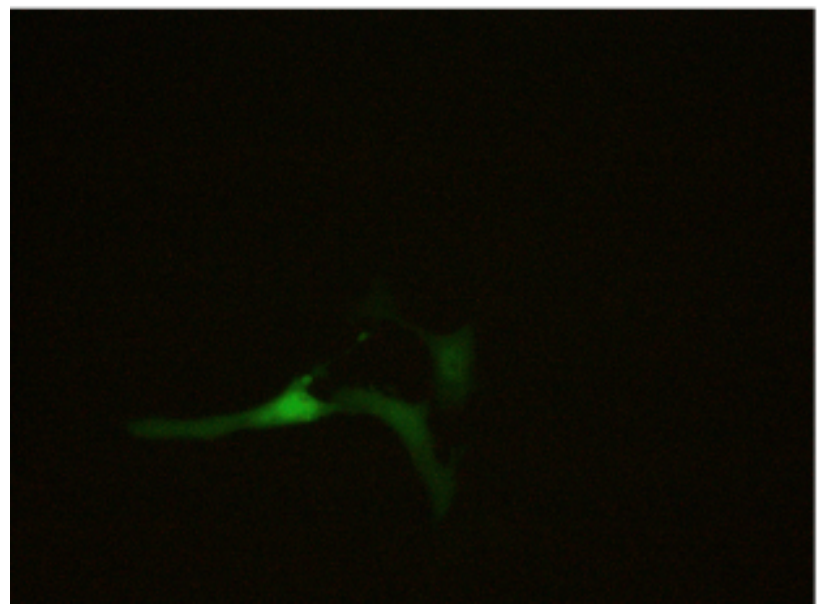

E

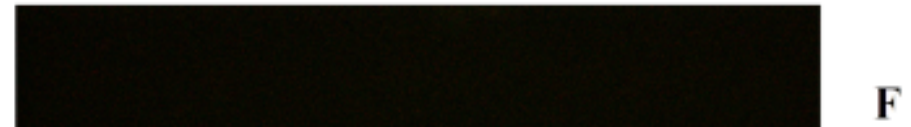

\section{Figure 16}

The transfected rat hepatocytes with PCDNA3-GLUT2-mutated preproinsulin-EGFP when 15 mM glucose added to the media X200. (A) The transfected rat hepatocytes after $24 \mathrm{~h}$ from transfection. (B) The transfected rat hepatocytes after 3 days from transfection. (C) The transfected rat hepatocytes after 5 days from transfection. (D) The transfected rat hepatocytes 7 days from transfection. (E) The transfected rat hepatocytes after 10 days from transfection. (F) The transfected rat hepatocytes after 12 days from transfection. 


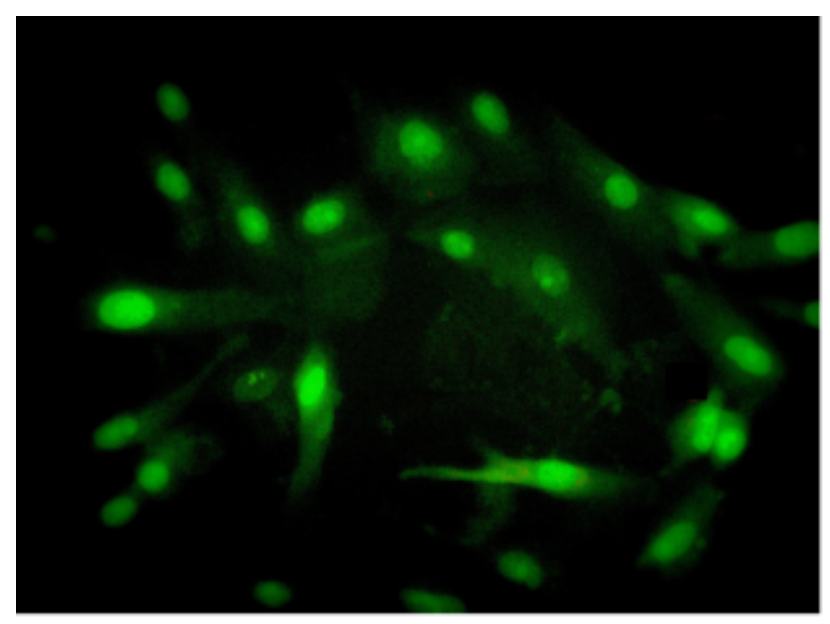

A
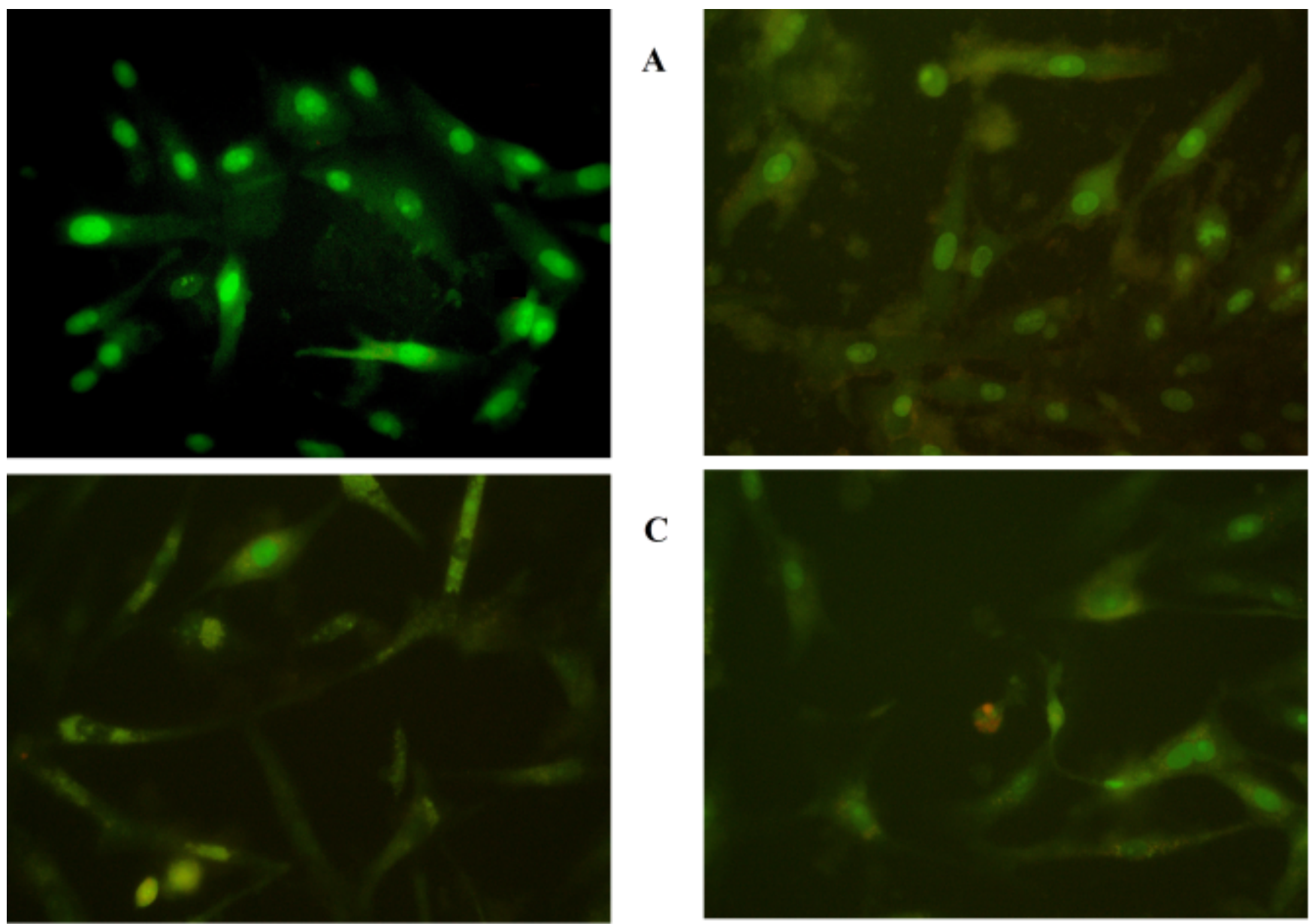

C

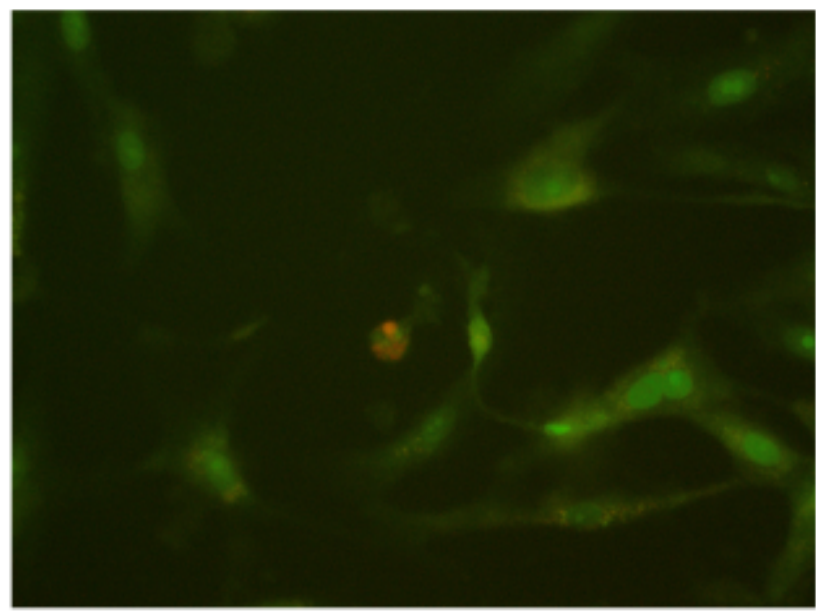

D

$\mathbf{E}$

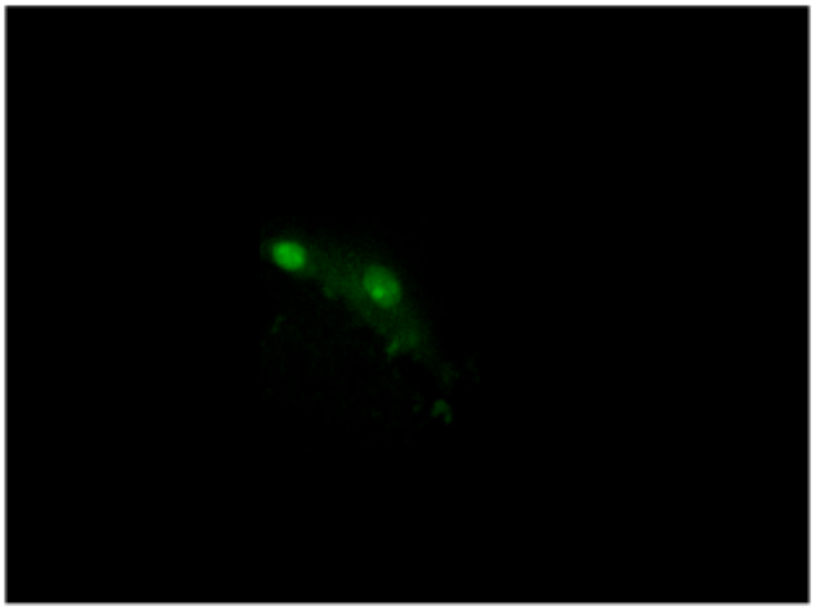

\section{Figure 17}

The transfected rat hepatocytes with PCDNA3-GLUT2-mutated preproinsulin-EGFP when 25 mM glucose added to the media X200. (A) The transfected rat hepatocytes after $24 \mathrm{~h}$ from transfection. (B) The transfected rat hepatocytes after 3 days from transfection. (C) The transfected rat hepatocytes after 5 days from transfection. (D) The transfected rat hepatocytes 7 days from transfection. (E) The transfected rat hepatocytes after 10 days from transfection. (F) The transfected rat hepatocytes after 12 days from transfection. 


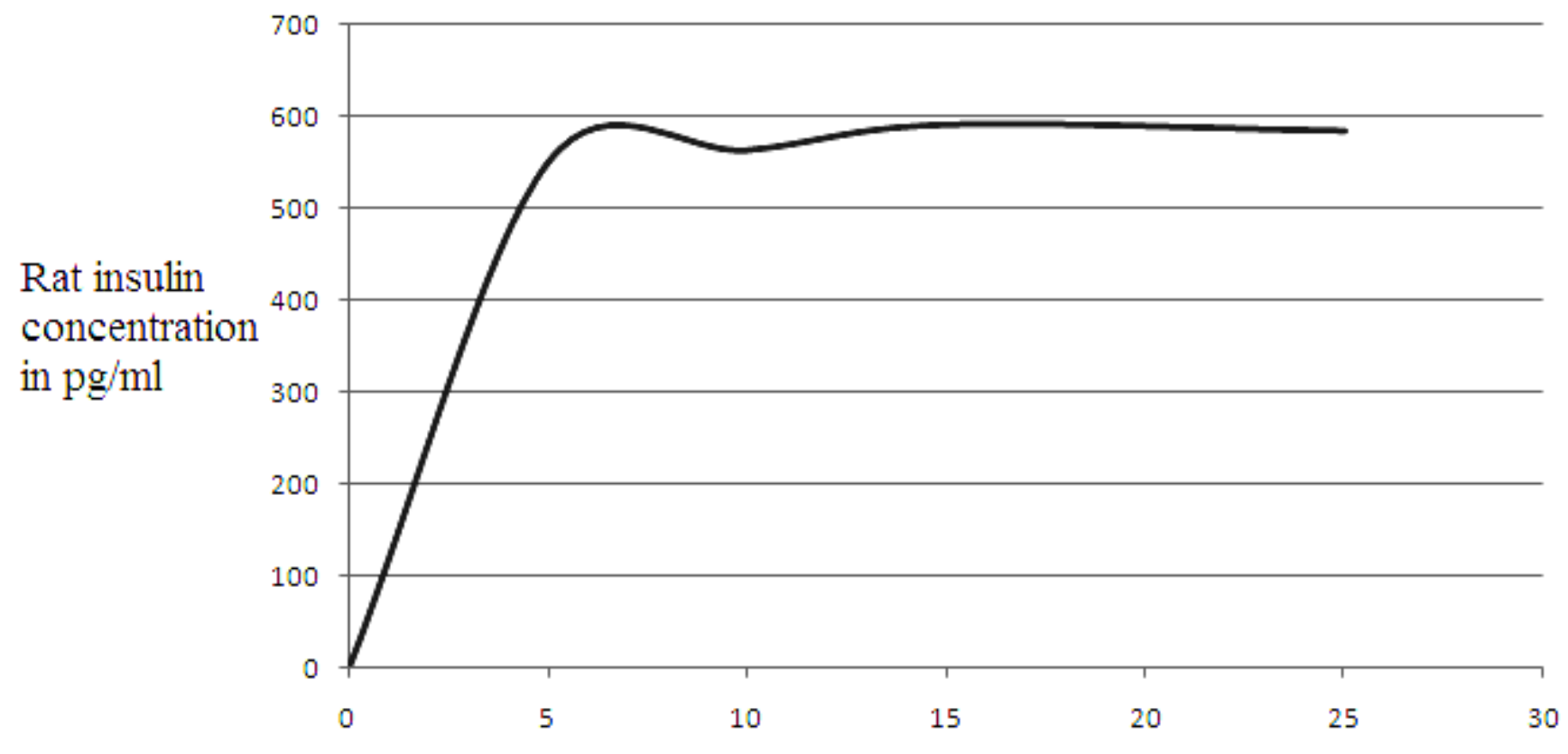

Glucose concentration in $\mathrm{mM}$

\section{Figure 18}

The relation between the concentration of insulin released corresponding to different doses of glucose in the cell lysate using the PCDNA3-GLUT2-mutated preproinsulin-EGFPconstruct. The amount of insulin released increased as the amount of glucose increased.

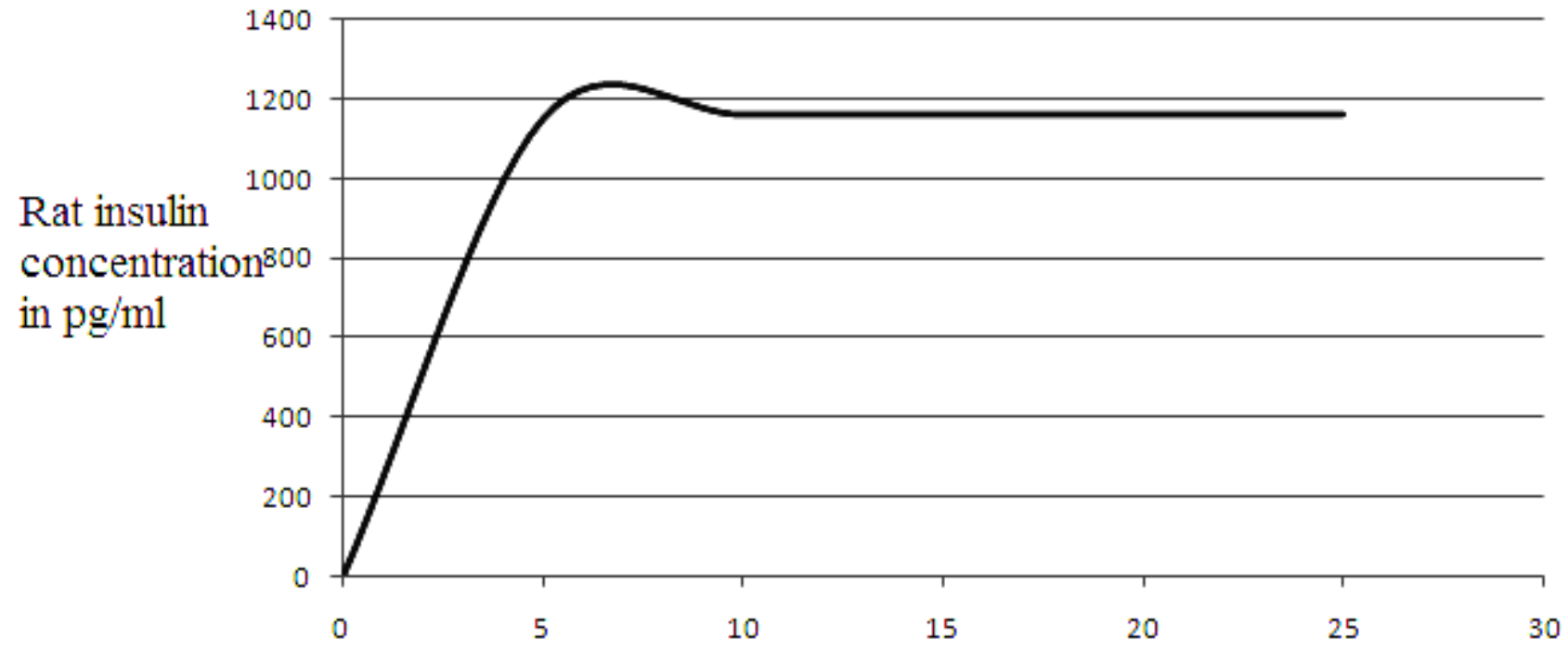

Glucose concentration in $\mathrm{mM}$

\section{Figure 19}

The relation between the concentration of insulin released corresponding to different doses of glucose in media using the PCDNA3-GLUT2-mutated preproinsulin-EGFPconstruct. The amount of insulin out to the 
media increased as the amount of glucose increased. 